\title{
Development of a novel small antibody that retains specificity for tumor targeting
}

\author{
Zi-Peng Zhen ${ }^{* \dagger 1,2}$, Jie Zhang ${ }^{\dagger 1}$ and Si-Yuan Zhang ${ }^{3}$
}

Address: ${ }^{1}$ Key Laboratory of Transplant Engineering and Immunology, Ministry of Health, West China Hospital, Sichuan University, Chengdu 610041, PR China, ${ }^{2}$ Linyi Normal University, Linyi, 276005, PR China and ${ }^{3}$ West China Cancer Center/Laboratory of Signal Transduction and Molecular Targeting Therapy, West China Hospital, Sichuan University, Chengdu 610041, PR China

Email: Zi-Peng Zhen* - zhzp1120@yahoo.com.cn; Jie Zhang - zjie992002@yahoo.com.cn; Si-Yuan Zhang - zhangsiyuan@126.com

* Corresponding author †Equal contributors

Published: 30 April 2009

Journal of Experimental \& Clinical Cancer Research 2009, 28:59 doi:10.1 186/1756-9966-28-59

This article is available from: http://www.jeccr.com/content/28/1/59

(c) 2009 Zhen et al; licensee BioMed Central Ltd.

This is an Open Access article distributed under the terms of the Creative Commons Attribution License (http://creativecommons.org/licenses/by/2.0), which permits unrestricted use, distribution, and reproduction in any medium, provided the original work is properly cited.
Received: 21 January 2009

Accepted: 30 April 2009

\begin{abstract}
Background: For the targeted therapy of solid tumor mediated by monoclonal antibody (mAb), there have different models of rebuilding small antibodies originated from native ones. Almost all natural antibody molecules have the similar structure and conformation, but those rebuilt small antibodies cannot completely keep the original traits of parental antibodies, especially the reduced specificity, which gravely influences the efficacy of small antibodies.
\end{abstract}

Methods: In this study, authors developed a novel mimetic in the form of $\mathrm{V}_{\mathrm{H}} \mathrm{FRI} \mathrm{C}_{\mathrm{C}-10^{-}} \mathrm{V}_{\mathrm{H}} \mathrm{CDRI}$ $\mathrm{V}_{\mathrm{H}} \mathrm{FR} 2-\mathrm{V}_{\mathrm{L}} \mathrm{CDR} 3-\mathrm{V}_{\mathrm{L}} \mathrm{FR} 4_{\mathrm{N}-10}$ for a parental $\mathrm{mAb}$ induced with human breast cancer, and the mimetic moiety was conjugated to the C-terminal of toxicin colicin la. The novel fusion peptide, named protomimecin (PMN), was administered to MCF-7 breast cancer cells to demonstrate its killing competency in vitro and in vivo.

Results: Compared with original antibody-colicin la (Fab-la) and single-chain antibody-colicin la (Sc-la) fusion proteins, PMN retained the targeting specificity of parental antibody and could specifically kill MCF-7 cells in vitro. By injecting intraperitoneally into BALB/c athymic mice bearing MCF-7 tumors, with reduced affinity, PMN significantly suppressed the growth of tumors compared with control mice treated by toxicin protein, Fab-la protein, Sc-la protein or by PBS $(p<0.05)$.

Conclusion: This novel mimetic antibody retained original specificity of parental antibody, and could effectively guide killer moiety to suppress the growth of breast cancer by targeted cell death.

\section{Background}

Targeted therapy with maximal effectiveness and minimal adverse effects is the ultimate goal for treatment of solid tumors $[1,2]$. Since the development of hybridoma and monoclonal antibody (mAb) technology [3,4], antibody therapy has emerged as the choice for targeted therapy for solid tumors because of the specific affinity of the antibody for the corresponding antigen, owing to the presence of six complementarity-determining regions (CDRs) in the variable domains of the heavy chain $\left(\mathrm{V}_{\mathrm{H}}\right)$ and that of light chain $\left(\mathrm{V}_{\mathrm{L}}\right)[3,5]$. However, although native antibodies have the highest specificity and affinity for antigens, they also have large molecular structures and the potency of penetrating into the core area of solid tumors cannot reach to the extent that scientists expect because of the "binding barrier"[6]. Single-chain Fvs (scFvs) contain the specificity of the parental antibody molecules, but they readily form aggregations [7]. Overlooking the syner- 
gistic antigen recognition relationship between $\mathrm{V}_{\mathrm{H}}$ and $\mathrm{V}_{\mathrm{L}}$ artificially rebuilt single-domain antibodies or micro-antibodies cannot completely keep the specificity and affinity of parental antibody $[8,9]$.

We proposed that the essential interface of antibody-antigen binding constrained by the molecular forces between $\mathrm{V}_{\mathrm{H}}$ and $\mathrm{V}_{\mathrm{L}}[10,11]$. For original antibody molecules, the constraint force derives from the 3-Dimension conformation of antibody molecules. Our small antibody was constructed in the following form: $\mathrm{V}_{\mathrm{H}} \mathrm{FR} 1_{\mathrm{C}-10}-\mathrm{V}_{\mathrm{H}} \mathrm{CDR} 1$ $\mathrm{V}_{\mathrm{H}} \mathrm{FR} 2-\mathrm{V}_{\mathrm{L}} \mathrm{CDR} 3-\mathrm{V}_{\mathrm{L}} \mathrm{FR} 4_{\mathrm{N}-10}$ (Fig. 1a). Antigen recognition by intact antigen-binding fragment (Fab) of immunoglobulin (Ig) is synergistically produced by all six CDRs in both $\mathrm{V}_{\mathrm{H}}$ and $\mathrm{V}_{\mathrm{L}}$ domain, CDR3 is located in the center of the antigen-recognition interface of the parental antibody and should be contained within the internal portion of the small antibody [12]. Another CDR domain selected was $\mathrm{V}_{\mathrm{H}} \mathrm{CDR} 1$ normally the closest to CDR3, which formed the synergistic interface with CDR3 for antigen-recognition $[8,9]$. The $\mathrm{V}_{\mathrm{H}} \mathrm{FR} 2$ segment linked the two CDRs and contains the least hydrophobic amino acid (aa) residues, increasing the water solubility of the mimetic complex. Finally, $\mathrm{V}_{\mathrm{L}} \mathrm{FR} 4_{\mathrm{N}-10}$ and $\mathrm{V}_{\mathrm{H}} \mathrm{FR} 2$ supported CDR3 to form the projected loop conformation, and the $\mathrm{V}_{\mathrm{H}} \mathrm{CDR}$ l loop was restrained on both sides by $\mathrm{V}_{\mathrm{H}} \mathrm{FR} 2$ and $\mathrm{V}_{\mathrm{H}} \mathrm{FR} 1_{\mathrm{C}-10}$ forming the other loop conformation. These selected components of the mimetic are original and not changed or substituted from the parental antibody. Guided by these reasons, we proposed that the construct of mimetic kept specificity similar to that of parental antibody (Fig. 1a).

In the present study, we constructed the small antibody consisting of $\mathrm{V}_{\mathrm{H}} \mathrm{FR} 1_{\mathrm{C} 10}-\mathrm{V}_{\mathrm{H}} \mathrm{CDR} 1-\mathrm{V}_{\mathrm{H}} \mathrm{FR} 2-\mathrm{V}_{\mathrm{L}} \mathrm{CDR} 3-$ $\mathrm{V}_{\mathrm{L}} \mathrm{FR} 4_{\mathrm{N} 10}$ conjugated in-line, as a mimetic molecule for a natural monoclonal IgG against human breast cancer cell envelope antigen c-erbB-2 $[13,14]$. The mimetic was then conjugated to the C-terminal of colicin Ia, a 70-kD member of the E1 colicin family of channel-forming bacteriocins that are bactericidal to Escherichia coli (E. coli) to obtain a fusion protein, named protomimecin (PMN; Fig. 1b, c), which enable us to demonstrate the ability of the mimetic to target cancer cells bearing specific surface antigens. Colicin Ia kills target cells by forming a voltage-activated channel in the cell membrane of target cells mediated by its C-terminal 175-residues, channel-forming domain which contains the killing competency of "one molecule, one kill" $[15,16]$. We demonstrated that PMN could effectively kill MCF-7 cells in vitro and suppress the growth of MCF-7 tumors in vivo. Based on our preliminary results, this novel model of reconstructing small antibodies may be further developed for targeted therapy of tumors.

\section{Methods \\ Cell lines and cell culture}

The hybridoma cell line HB-8696 was purchased from ATCC and grown in Dulbecco's modified Eagle Medium (DMEM) and fortified with penicillin-streptomycin (100 $\mathrm{U} / \mathrm{ml}, 100 \mu \mathrm{g} / \mathrm{ml}$ respectively) and $10 \%$ fetal bovine serum (FBS). Medium was changed every 2-3 days. The breast cancer cell lines, $\mathrm{Zr}-75-30$ and MCF-7, and the Burkitt's Lymphoma cell line, Raji (obtained from the Laboratory of Transplant Immunology and the Department of Laboratory Medicine, Division of Clinical Immunology, West China Hospital) were grown in RPMI 1640 medium containing double antibiotics and 10\% FBS. Medium was changed every 2-3 days. All cell lines were incubated at $37^{\circ} \mathrm{C}$ in $5 \% \mathrm{CO}_{2}$ incubator (Sanyo Electro. Biomed. Japan).

\section{The preparation of parental antibody $520 C 5$ and toxicin colicin Ia}

HB-8696 murine hybridoma cells were grown to a density of $10^{7}$ cells $/ \mathrm{ml}$. Under sterility and $4^{\circ} \mathrm{C}$, the cells were removed from the medium by centrifugation at 1000 a

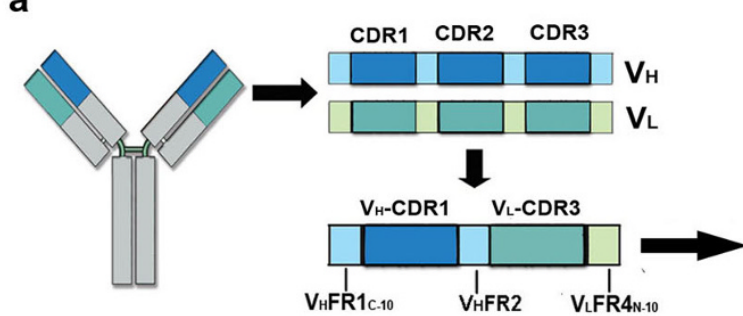

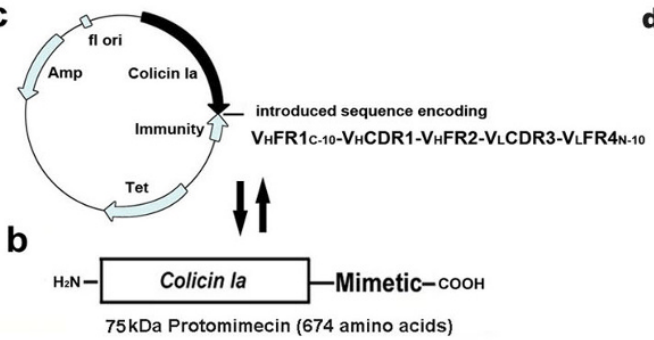

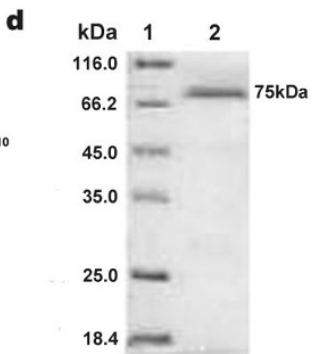

\section{Figure I}

Schematic diagram for the process of constructing the small antibody and the fusion peptide. (a) The small anti-

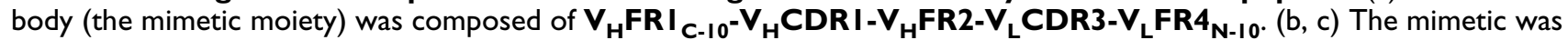
conjugated to the $\mathrm{C}$-terminal of wild-type colicin la to construct the conjugated peptide, named protomimecin (PMN). (d) The I5\% SDS- PAGE migration map of the fusion peptide PMN. 
$\mathrm{rpm}$, and the supernatant (containing the original mAbs 520C9 that are the parental antibody of the mimetic peptide molecules) was further purified by centrifugation at $10,000 \mathrm{~g}$. The following purification procedure was done according to purification kit' protocol (Millipore). The purified antibodies were stored at $-20^{\circ} \mathrm{C}$ for subsequent experiments.

The $\mathrm{p}^{\text {SELECT }} 1$ plasmids (from the Key Laboratory of Transplant Engineering and Immunology, Ministry of Health, West China Hospital, Sichuan University, China) that contain the colicin Ia gene and the reversed direction immunity protein gene of colicin Ia were transformed into competent TG1 cells. Then spread those TG1 cells on FB agar medium containing $25 \mu \mathrm{g} / \mathrm{ml}$ ampicillin and cultivated at $37^{\circ} \mathrm{C}$ for $12-16$ hours under humidity and screening TG1 cells containing $\mathrm{p}^{\text {SELECT }}-1$ plasmids, and the positive clones were selected to cultivate rotatorily at 180 $\mathrm{rpm}$ in $2 \mathrm{ml} \mathrm{FB}$ medium containing $50 \mu \mathrm{g} / \mathrm{ml}$ ampicillin under the same condition as above mentioned for overnight, then carefully dumped to $60 \mathrm{ml} \mathrm{FB}$ medium for continuous cultivation for 5-6 hours. Until the total volume of medium reached $8 \times 600 \mathrm{ml}$ and the OD for TG1 cells reached 0.5 under same culture condition, centrifuged those cells at $6,000 \mathrm{~g}$ for 17 minutes under $4{ }^{\circ} \mathrm{C}$, and resuspended precipitate in $60-80 \mathrm{ml}$ borate buffer $(50$ mM borate buffer, $\mathrm{pH} 9.0$, with $2 \mathrm{mM}$ EDTA) containing $0.5 \mathrm{mM}$ phenylmethylsulfonyl fluoride. The cells were sonicated and debris removed by centrifugation for 90 min at $75,000 \mathrm{~g}$ under $4^{\circ} \mathrm{C}$. Nucleic acids were precipitated by addition of $1 / 5$ volume streptomycin sulfate $(25 \%)$. Supernatants were dialyzed against borate buffer for 12 hours (changing the buffer every $5-6$ hours) at $4{ }^{\circ} \mathrm{C}$ then applied to the $\ddot{A} K T A^{\mathrm{TM}}$ prime protein purification system $(2.5 \times 12 \mathrm{~cm}$ CM-Sepharose column, Amersham Pharmacia Biocech). Proteins were recovered at $4^{\circ} \mathrm{C}$ by gradient elution with $0.1,0.2$ and $0.3 \mathrm{M} \mathrm{NaCl}$ in borate buffer and collected in $0.5 \mathrm{ml}$ fractions. The harvested colicin Ia was dialyzed against PBS (pH 7.4-7.5) for 12 hours at $4{ }^{\circ} \mathrm{C}$, and stored at $-80^{\circ} \mathrm{C}$ freezer for subsequent experiments.

\section{The scanning of $V_{H}$ and $V_{L}$ domain DNA sequences of original antibody}

$\mathrm{V}_{\mathrm{H}}$ and $\mathrm{V}_{\mathrm{L}}$ domain genes for mAb A520C9 IgG were isolated from HB-8696 mouse hybridoma cell. Total RNA was extracted and amplified by RT-PCR (Takara RNA PCR Kit (AMV Ver.3.0)) using the following primers: H-chain: 5'-ACTAGTCGACATGGCTGTCYTRGBGCTGYTCY TCTG3'and 5'-CCCAAGCTTCCAGGGRCCARKGGATARACWGRTGG-3'; L-chain: 5'-GGGAATTCATGGAGACAGACA CACTCCTGCTAT-3'and 5'-CCCAAGCTTACTGGA TGGTGGGAAGATGGA-3', purified RT-PCR products were ligated into the plasmids pMD18-T, purchased from Takara. The DNA sequences of plasmids were isolated and analyzed to determine the genes of $\mathrm{V}_{\mathrm{H}}$ and $\mathrm{V}_{\mathrm{L}}$ domains of $\mathrm{mAb}$.

Amino acid sequences of peptides from parental antibody The aa sequences of all six CDRs in the parental antibody 520C9 Fab are:

$\mathrm{V}_{\mathrm{H}}: \mathrm{H}_{2} \mathrm{~N}$-EMQLVESGPEVKKPGASVKVSCKASGYTFTNYGMNWVRQAPGQGLEWM GWINTYTGQSTYAD DFKERVTMTTDTSTSTAYDMLRSLRSDDTAVYYCARRFGFAYWQ GTLVVSS-COOH (bold letters represent CDR domain)

$\mathrm{V}_{\mathrm{L}}: \mathrm{H}_{2} \mathrm{~N}$-DIQMTQSPSSLSASVGDRVTITCRASQDIGN SLTWYQQKPGKTPKLLIYATS SLDSGVPSRFSGSGSG TDFTFTISSLQPEDIATYYCLQYAIFPYTFGQGTRLEIK-

$\mathrm{COOH}$ (bold letters represent CDR domain)

The sequence of the single-chain $\mathrm{Fv}(\mathrm{ScFv})$ for the parental antibody 520C9 is:

$$
\mathrm{V}_{\mathrm{H}^{-}}(\mathrm{GGGGS})_{3}-\mathrm{V}_{\mathrm{L}}[17]
$$

The sequence of the $\mathrm{V}_{\mathrm{H}} \mathrm{FR} 1_{\mathrm{C}-10}-\mathrm{V}_{\mathrm{H}} \mathrm{CDR} 1-\mathrm{V}_{\mathrm{H}} \mathrm{FR} 2-\mathrm{V}_{\mathrm{L}} \mathrm{CDR} 3-$ $\mathrm{V}_{\mathrm{L}} \mathrm{FR} 4_{\mathrm{N}-10}$ mimetic of the parental antibody is:

\section{$\mathrm{H}_{2} \mathrm{~N}$-SCKASGYTFTNYGMNWVRQAPGQGLEWMGL} QYAIFPYTFGQGTRLEIK-COOH

\section{Preparation of the mimetic moiety and conjugated peptide}

The DNA sequences for the $\mathrm{V}_{\mathrm{H}} \mathrm{FR} 1_{\mathrm{C}-10}, \mathrm{~V}_{\mathrm{H}} \mathrm{CDR} 1, \mathrm{~V}_{\mathrm{H}} \mathrm{FR} 2$, $\mathrm{V}_{\mathrm{L}} \mathrm{CDR} 3$ and $\mathrm{V}_{\mathrm{L}} \mathrm{FR} 4_{\mathrm{N}-10}$ regions of the 520C9 Fab were conjugated to follow position I626 of colicin Ia by double-stranded oligonucleotide mutagenesis (QuickChange kit, Stratagene) using the $\mathrm{p}^{\text {SELECT }} 1$ plasmid that contains the colicin Ia gene and the reversed direction immunity protein gene of colicin Ia to form colicin Ia- $\mathrm{V}_{\mathrm{H}} \mathrm{FR} 1_{\mathrm{C}-10^{-}}$ $\mathrm{V}_{\mathrm{H}} \mathrm{CDR} 1-\mathrm{V}_{\mathrm{H}} \mathrm{FR} 2-\mathrm{V}_{\mathrm{L}} \mathrm{CDR}_{3}-\mathrm{V}_{\mathrm{L}} \mathrm{FR} 4_{\mathrm{N}-10}$ (Fig. 1). The oligonucleotides used contained the desired mutations for SCKASGYTFTNYGMNWVRQAPGQGLEWMGLQYAI FPYTFG QGTRLEIK were 5'-GCG AAT AAG TTC TGG GGT ATT TCC TGC AAG GCT TCT GGT TAC ACC TTT ACC TAA ATA AAA TAT AAG ACA GGC-3', 5'-GCT TCT GGT TAC ACC TTT ACC AAC TAT GGA ATG AAC TGG GTG CGA CAG GCC TAA ATA AAA TAT AAG ACA GGC-3', 5'-ATG AAC TGG GTG CGA CAG GCC CCT GGA CAA GGG CTT GAG TGG ATG GGA CTA TAA ATA AAA TAT AAG ACA GGC-3', 5'-GGG CTT GAG TGG ATG GGA CTA CAA TAT GCT ATT TTT CCG TAC ACG TTC GGC TAA ATA AAA TAT AAG ACA GGC-3' and 5'-ATT TTT CCG TAC ACG TTC GGC CAA GGG ACA CGA CTG GAG ATT AAA TAA ATA AAA TAT AAG ACA GGC-3' (boldface triplets represent inserted sites). 
Plasmids containing inserted DNA sequences were transformed into competent TG1 E. coli, and cells were grown in FB medium containing $50 \mu \mathrm{g} / \mathrm{ml}$ ampicillin. The procedures of cultivating TG1 cells and purifying conjugated peptides were the same as that of preparing colicin Ia protein.

In vitro killing activity, Immunolabeling and affinity assays ZR-75-30, MCF-7, and Raji cells were grown in the Falcon 3046 six-well cell culture plates (Becton Dickinson Co.) under the same condition as that of above described. 24 hours later, 5-125 $\mu \mathrm{g} / \mathrm{ml}$ PMN, wild type colicin Ia (wt Ia), parental antibody-colicin Ia fusion protein (Fab-Ia), single-chain antibody-colicin Ia fusion protein (Sc-Ia) (CL(Xi'an) Bio-scientific) and nonrelative control protein, low molecular weight marker protein (LWMP, purchased from Takara) were respectively added to the cell culture wells. After co-incubating for 24 hours, the living and dead cells were stained with $50 \mathrm{nM}$ acridine orange and $600 \mathrm{nM}$ propidium iodide and staining was imaged using a digital data collection system under an inverted fluorescent microscope (IX-71, Olympus) using U-MWU2, UMNB2 and U-MNG2 filters. For the comparison of killing competency presented by those agents with each other, we selected five image fields to respectively count the number of dead and living cells in every culture well after 24, 48 and 72 hours.

MCF-7 cell were grown in 1640 medium for $72 \mathrm{~h}$, fixed in $10 \%$ paraformaldehyde for $40 \mathrm{~min}$ at room temperature, then $100 \mu$ l fixed cells $\left(10^{6} / \mathrm{ml}\right)$ were incubated with $10 \mu \mathrm{l}$ PBS, LWMP, Fab, Sc (CL(Xi'an) Bio-Scientific) and PMN respectively with different concentration $\left(10^{2}-10^{-1} \mathrm{nM}\right)$ for $1 \mathrm{hr}$ at $37^{\circ} \mathrm{C}$, then incubated with parental antibody for $40 \mathrm{~min}$ at $37^{\circ} \mathrm{C}$ and fluorescein isothiocyanate (FITC) labeled second antibody (Pierce) for $30 \mathrm{~min}$ at $37^{\circ} \mathrm{C}$. After incubating with DAPI for 25 minutes at $37^{\circ} \mathrm{C}$, the mean fluorescent intensity of per 1,500 cells was measured by BD FACSCanto Flow Cytometer (BD Biosciences). For concentration-dependent inhibitory experiments against the killing activity of PMN, different concentrations of either parental A520C9 mAbs, or synthetic $\mathrm{V}_{\mathrm{H}} \mathrm{FR} 1_{\mathrm{C}-10}-\mathrm{V}_{\mathrm{H}}$ CDR1-V $\mathrm{H}$ FR2-V $\mathrm{L}_{\mathrm{L}}$ CDR3-V $\mathrm{L}_{\mathrm{L}} 4_{\mathrm{N}-10}$ (South West University) were added with PMN $(75 \mu \mathrm{g} / \mathrm{ml})$ to incubate with MCF-7, Zr-75-30 or Raji cells, respectively $\left(10^{2}-10^{-1} \mathrm{nM}\right)$, then living and dead cells were counted with $0.2 \%$ Trypan blue under an inverted microscope (IX71, Olympus).

The MCF-7 cells were grown and fixed as the above-mentioned procedure. Then original antibodies (OAbs) and the mimetic peptides were diluted to 100, 10, 1 and 0.1 $\mu \mathrm{mol} / \mathrm{L}$ by PBS (pH7.45), respectively. The indirect enzyme-linked immunosorbent assays (ELISA) were introduced to analysis the relative affinity of the mimetics and OAbs to antigens. The value of absorbance at $490 \mathrm{~nm}$ wavelength was inspected by microplate reader (Bio-Rad), which was used to determine the concentration of the OAbs and the mimetics when the saturation of Abs to antigens reached to one percent. The relative affinity was compared between OAbs and the mimetics at 50\% saturation of Abs to antigens.

\section{In vivo activity and the biodistribution of PMN}

MCF-7 cells were grown under the same condition as that of above described, and collected by centrifugation at 1,000 rpm. Cells were resuspended in FBS-free medium at a concentration of $10^{8}$ cells $/ \mathrm{ml}$. Twenty-five $4-5$-week-old female BALB/c athymic nude mice weighing 16-20 g were purchased from the Experimental Animal Center of West China Hospital. Before implanting tumor cells, mice were allowed to acclimatize for 3 days. A total of $6-7 \times 10^{7}$ MCF-7 cells were subcutaneously (s.c.) implanted into the left armpit of mice. Tumor growth was monitored daily until the average sizes of tumors reached $5 \times 5 \times 5 \mathrm{~mm}$, then randomly separated those mice to the treatment group (PMN group; $\mathrm{n}=5$ ), wild type colicin Ia group (wt Ia group; $n=5)$, Fab-Ia group $(n=5)$, Sc-Ia group $(n=5)$ and the PBS control group (PBS group; $\mathrm{n}=5$ ), and the treatment course began. The PMN group was treated with intraperitoneal (i.p.) injection of PMN at 1,200 $\mu \mathrm{g} /$ mouse/day $(400 \mu \mathrm{g} / 8$ hours, tid; $\mathrm{n}=5)$. The wt Ia group, Fab-Ia group, Sc-Ia group and the PBS group were injected with wt Ia protein, Fab-Ia protein, Sc-Ia protein $(400 \mu \mathrm{g} / 8$ hours, i.p. tid; $n=5)$ and PBS ( $450 \mu \mathrm{l} / 8$ hours, i.p. tid; $\mathrm{n}$ = 5), respectively. Animals had free access to standard food and water throughout the treatment course. After 14 days, all mice were sacrificed to collect tumors and organs for weighing and for histopathological inspection.

$150 \mu \mathrm{g}$ PMN proteins labeled by FITC (EZ-labeled FITC protein labeling kit, pierce) were ip injected into BALB/c mice $(n=5)$, weighing $16-20 \mathrm{~g}$, inoculated MCF-7 cells at armpit for 2 weeks. 2.5 hours later, the mice were fastened supinely on a black board under ether inhalation. When the in vivo inspections completed, the mice were sacrificed and the tumors and vital organs were sectioned. The images were observed with the LT-99D2 Illumatool Dual Light System (excitation $470 \mathrm{~nm}$, emission $515 \mathrm{~nm}$, Lightool Research) and recorded by a built-in camera.

\section{Assessment of toxicity of PMN}

Kunming normal mice (purchased from Experimental Animal Center of West China Hospital, Sichuan University, China), weighing 15-25 g were injected with either PMN (100-2,500 $\mu \mathrm{g} /$ mouse/day, $\mathrm{n}=5)$ or PBS $(\mathrm{n}=5)$ intraperitoneally each day. After 3 weeks of administration, mice were sacrificed for histopathological inspection and blood samples were collected for indirect enzymelinked immunosorbent assay (ELISA) to screen potential antibodies. 
The Institutional Animal Care and Use Committee of Sichuan University and Project of Sichuan Animal Experiment Committee (license 045) approved the animal use and in vivo experiments.

\section{Electrophoresis}

$0.9 \%$ agarose electrophoresis was applied to authenticate the reconstructed plasmids and 15\% sodium dodecyl sulfate polyacrylamide gel electropheresis (SDS-PAGE) was applied to authenticate the harvested protein, respectively.

\section{Statistical analysis}

SPSS version 11.0.1 for Microsoft Windows was used for statistical analysis. Two-tailed $t$-tests were performed using GraphPad Prism for Windows version 4.00. $P<0.05$ was considered to be a statistically significant difference.

\section{Results}

\section{Production and purification of PMN}

Plasmids containing the colicin Ia gene and the reversed direction immunity protein gene of wt Ia protein were used to conjugate signal-moiety with wt Ia (Fig. 1c). We conjugated the 48-aa residues to the C-terminal of wt Ia by five mutation steps, with the same PCR reaction conditions $\left(95^{\circ} \mathrm{C}, 35 \mathrm{sec}\right.$ for denaturation; $53^{\circ} \mathrm{C}, 70 \mathrm{sec}$ for annealing; $68^{\circ} \mathrm{C}, 17 \mathrm{~min}$ for elongation; which repeated 18 times). Plasmid migration in agarose electrophoresis $(0.9 \%)$ was applied to confirm transmutated plasmid at each step (data not shown). After the last round of PCR, the harvested plasmid was transformed into competent TG1 E. coli to produce the PMN protein.

PMN protein was eluted with $0.2 \mathrm{M} \mathrm{NaCl}$ borate buffer. The original molecular weight of wt Ia is $\sim 70 \mathrm{kDa}$ and, with the addition of the 48-aa residues (approximately 5.3 $\mathrm{kDa}$ ), the molecular weight of PMN is $75 \mathrm{kDa}$, which was confirmed by SDS-PAGE migration image (Fig. 1d).

\section{In vitro killing activity and specificity of PMN}

Against MCF-7 cells, PMN molecules presented dramatic killing competency. Compared with Fab-Ia and Sc-Ia, who both presented obvious killing competency to MCF-7 cells, the killing competency of PMN molecule to MCF-7 cells was significantly superior to them ( $p<0.05$, Fig. $2 a)$. The killing activity of PMN presented time- and concentration-dependent characteristics. Of these cells, about $70-85 \%$ of the MCF-7 cells were killed within 48-72 hours after exposure to the PMN at concentration $75 \mu \mathrm{g} /$ $\mathrm{ml}$ ( $\mathrm{p}<0.001$; Fig. 2b) and 72 hours after incubating, PMN presented no obvious killing effect on MCF-7 cells at concentration $5 \mu \mathrm{g} / \mathrm{ml}$, but killed $80 \%$ of cells at concentration $75 \mu \mathrm{g} / \mathrm{ml}$ (Fig. 2c). Neither wt Ia protein nor the nonrelative LWMP could kill MCF-7, Zr-75-30 and Raji cells up to the maximal tested concentration at any time points $(125 \mu \mathrm{g} / \mathrm{ml}) .72$ hours co-incubation of Zr-75-30 and Raji with Fab-Ia, Sc-Ia, PMN and LWMP peptide molecules at any concentration did not significantly affect the viability of these cells relative to untreated control (Fig. 2a).

We assessed the antigen-recognition capabilities of PMN, Fab, Sc-Fv, LWMP and wt Ia peptides against MCF-7 cell by competition with the parent antibody. The results indicated that the $\mathrm{V}_{\mathrm{H}} \mathrm{FR} 1_{\mathrm{C}-10}-\mathrm{V}_{\mathrm{H}} \mathrm{CDR} 1-\mathrm{V}_{\mathrm{H}} \mathrm{FR} 2-\mathrm{V}_{\mathrm{L}} \mathrm{CDR} 3-$ $\mathrm{V}_{\mathrm{L}} \mathrm{FR} 4_{\mathrm{N}-10}$ mimetic had nearly the same extent effect on blocking binding of the parent antibody as Fab and Sc-Fv peptides (Fig. 3a). The concentration of the mimetic peptides that could induce $50 \%$ saturation of antigen was about 10 15\% that of OAbs (Fig. 3b). The killing activity of PMN molecules against MCF-7 cells could be inhibited up to $90 \%$ by increasing concentrations of OAbs or synthetic $\quad \mathrm{V}_{\mathrm{H}} \mathrm{FR} 1_{\mathrm{C}-10}-\mathrm{V}_{\mathrm{H}} \mathrm{CDR} 1-\mathrm{V}_{\mathrm{H}} \mathrm{FR} 2-\mathrm{V}_{\mathrm{L}}$ CDR3- $\mathrm{V}_{\mathrm{L}} \mathrm{FR} 4_{\mathrm{N}-10}$ mimetic molecules (Fig. 3c, d).

\section{In vivo activity and the biodistribution of PMN}

PMN, Fab-Ia and Sc-Ia agents were administered to tumor-bearing BALB/c nude mice at 1,200 $\mu \mathrm{g} / \mathrm{mouse} / \mathrm{day}$ (400 $\mu \mathrm{g} / 8$ hours, i.p. tid). Compared with the control groups treated by PBS, wt Ia, Fab-Ia and Sc-Ia agents, PMN effectively suppressed the growth of MCF-7 tumors in vivo (Fig. 4a). At the end of the consecutive 14-day treatment, the total tumor weight was significantly low in the PMN treatment group by about $45 \%$ compared with the other control groups $(p<0.05$; Fig. $4 b)$.

The fluorescence images revealed the targeting accumulation in MCF-7 tumor location within 2.5 hours after intraperitoneal injection (Fig. 4c). There were no same extent accumulations found in other vital organs except the intestine (Fig. 4d).

\section{The bio-safe assessment of PMN}

Those immunocompromised mice bearing tumors and those normal Kunming mice both treated by PMN remained health and gained body weight during the experimental course. Indirect ELISA found no detectable antibodies against respective epitopes in normal mice after 3 weeks treatment with different concentration PMN. The histopathological detection found no microscopic evidences of necrosis, inflammation or lymphocyte infiltration in the livers, spleens, kidneys and intestines from normal mice (data not shown).

\section{Histopathological analysis}

We found numerous fibrous foci in tumors from the PMN-treated group (Fig. 5b), which were not observed in the control groups' tumors (Fig. 5a). No microscopic evidence of metastasis, necrosis, inflammation or lymphocyte infiltration was detected in the livers, spleens, 


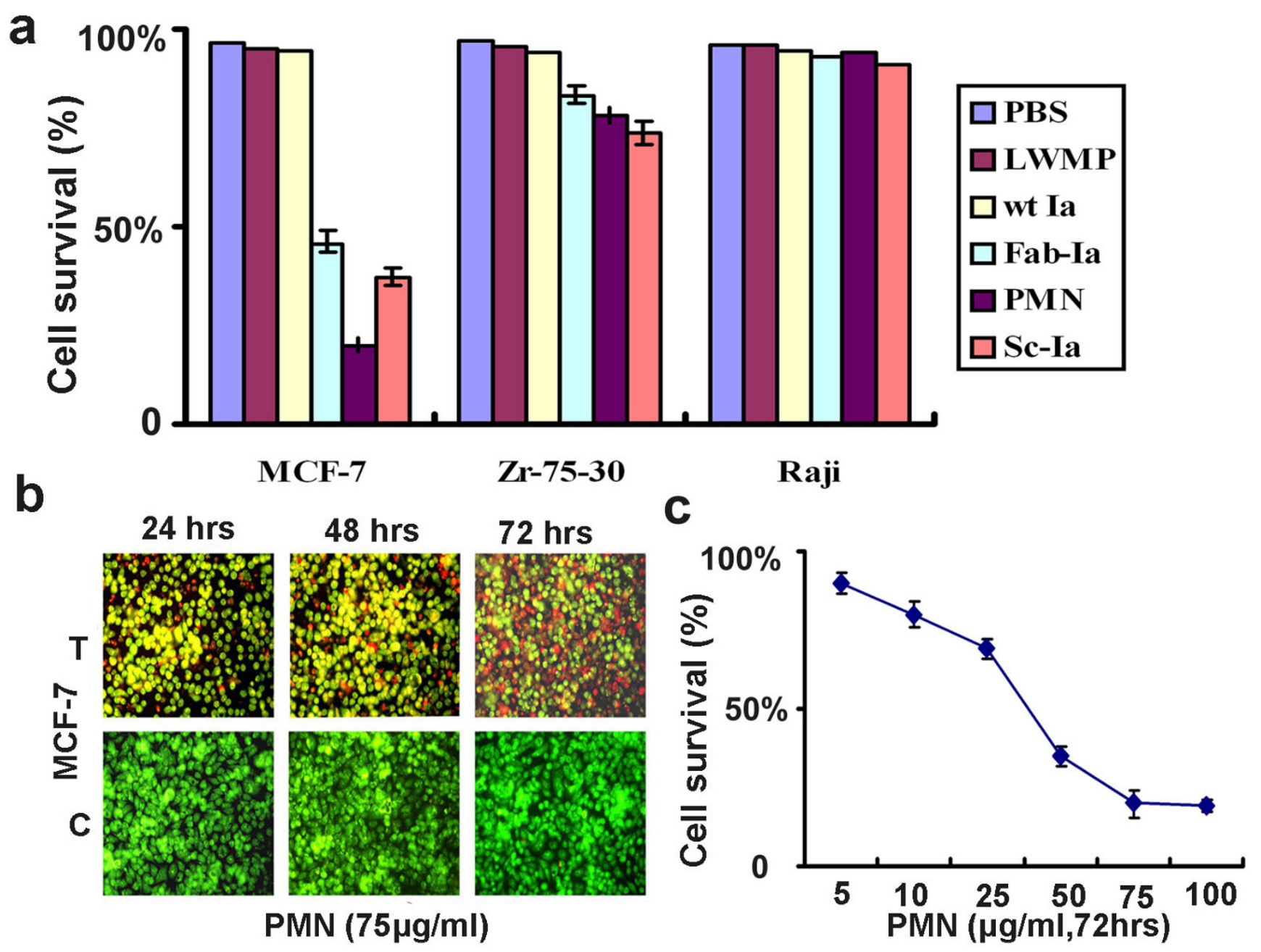

Figure 2

In vitro killing activity assays of PMN. (a) Killing effects of PBS, non-relative LWMP, wt la, Fab-la, PMN and Sc-la on MCF7, Zr-75-30 and Raji cells lines. LWMP, low molecular weight marker protein; wt la, wild-type colicin la; Fab-la, Fab segment from original antibody-colicin la fusion peptide; PMN, protomimecin; Sc-la, ScFv segment from original antibody-colicin la fusion peptide. (b) MCF-7 breast cancer cells were incubated with $75 \mu \mathrm{g} / \mathrm{ml}$ PMN for 24, 48 and 72 hrs, respectively. And tumor cells were stained with acridine orange (green color) and propidium iodide (red color). Red spots, dead cell mass; Green spots, live cell. After co-incubation for 72 hrs, approximately $80 \%$ of all MCF-7 cells had died (upper panel). T, PMNtreated group; C, control group treated with PBS. (c) Cytotoxicity of different concentration of PMN against MCF-7.

kidneys and intestines from $\mathrm{BALB} / \mathrm{c}$ mice (data not shown).

\section{Discussion}

In this study, we introduced a new model of reconstructing small antibody for targeted therapy of solid tumors, considering that the proper CDRs loops could not automatically form in the medium without the constraint force, which made the working conformation for the antigen-antibody interaction could not maintained [18]. We added two frameworks without any residue substitutions from original ones to both ends of two selected CDRs to restrain their conformation for the following three rea- sons. First, sustaining both CDRs as protruding loop structures should increase the probability of accessing target epitopes of specific antigens [19]. Second, for the mimetic, constraining the conformation of CDRs should reduce the probability of forming improper conformations and increase the efficiency of antigen-recognition by the proper conformation $[8,20]$. Third, the interactions among the framework moieties of the mimetic molecules should most effectively simulate the same kind of constraint force that exists among the frameworks of original antibody molecules $[8,11,20]$. Guided by those reasons, we posited that adding two restricted frameworks, with one at each end, could further constraint the conforma- 

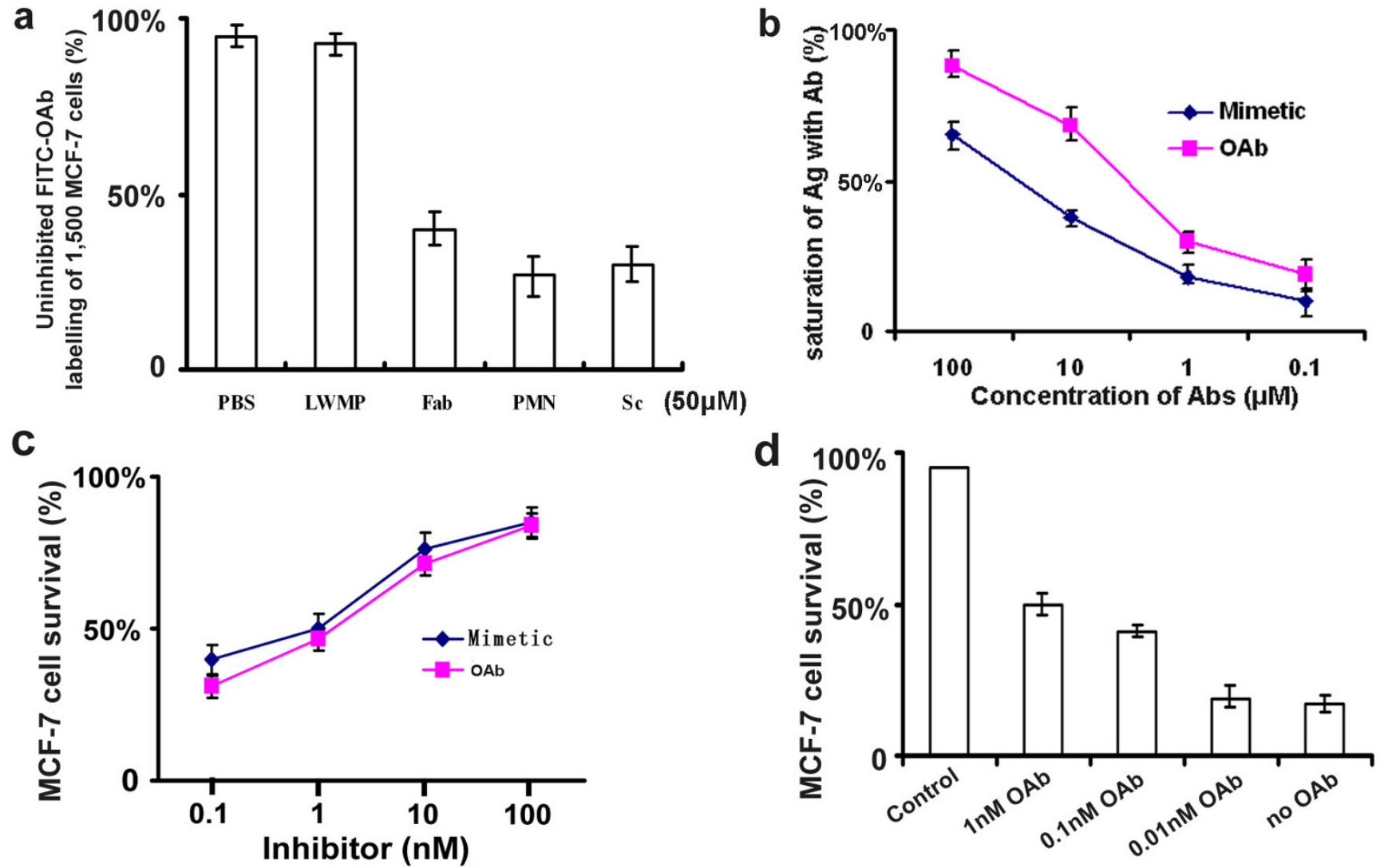

Figure 3

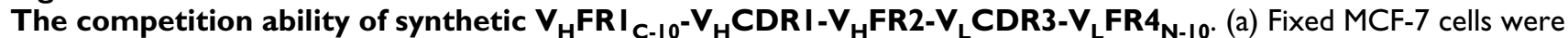
incubated with PBS, LWMP, Fab, PMN and Sc-Fv peptides $(50 \mu \mathrm{M})$ and DAPI $(50 \mathrm{ng} / \mathrm{ml})$ prior to flow cytometry. LWMP, low molecular weight marker protein; Fab, Fab segment from original antibody; PMN, protomimecin; Sc-Fv, ScFv segment from original antibody. (b) The relative affinity of $\mathrm{V}_{\mathrm{H}} \mathrm{FRI} \mathrm{I}_{\mathrm{C}-10}-\mathrm{V}_{\mathrm{H}} \mathrm{CDRI}-\mathrm{V}_{\mathrm{H}} \mathrm{FR2}-\mathrm{V}_{\mathrm{L}} \mathrm{CDR} 3-\mathrm{V}_{\mathrm{L}} \mathrm{FR} 4_{\mathrm{N}-10}$ peptides and $\mathrm{OAbs}$ to antigen. OAb, original antibody. (c) Concentration-dependent inhibition of different concentration of synthetic mimetic antibody or OAb against $75 \mu \mathrm{g} / \mathrm{ml}$ PMN. (d) MCF-7 cell survival ratio of the inhibition activity of OAb against PMN (75 $\mu \mathrm{g} / \mathrm{ml})$. OAb, original $m A b$ antibody $A 520 C 9$.

tion of $\mathrm{V}_{\mathrm{H}} \mathrm{CDR} 1$ and $\mathrm{V}_{\mathrm{L}} \mathrm{CDR} 3$ loops in the mimetic. Based on previous studies [10], we proposed that the length of the two framework fragments should be at least 10-aa. Therefore, the C-terminal 10-aa residues of $\mathrm{V}_{\mathrm{H}} \mathrm{FR} 1$ $\left(\mathrm{V}_{\mathrm{H}} \mathrm{FR} 1_{\mathrm{C}-10}\right)$ were attached to the $\mathrm{N}$-terminal of $\mathrm{V}_{\mathrm{H}} \mathrm{CDR} 1$ and the $\mathrm{N}$-terminal 10-aa residues of $\mathrm{V}_{\mathrm{L}} \mathrm{FR} 4\left(\mathrm{~V}_{\mathrm{L}} \mathrm{FR} 4_{\mathrm{N}-10}\right)$ were attached to the C-terminal of $\mathrm{V}_{\mathrm{L}} \mathrm{CDR} 3$ to form $\mathrm{V}_{\mathrm{H}} \mathrm{FR} 1_{\mathrm{C}-10}-\mathrm{V}_{\mathrm{H}}$ CDR1-V $\mathrm{H}$ FR2-V $\mathrm{V}_{\mathrm{L}}$ CDR3-V $\mathrm{L}_{\mathrm{LR}} 4_{\mathrm{N}-10}$ that could produce the constraint force by which the proper CDR1 and CDR3 loops formed.

Our findings suggested the proper loops of $\mathrm{V}_{\mathrm{H}} \mathrm{CDR} 1$ and $\mathrm{V}_{\mathrm{L}} \mathrm{CDR} 3$ were sustained in our small antibody model. The competition test to assess inhibition of PMN binding to specific antigens by parental antibody and synthetic mimetic demonstrated that the mimetic model without any substitution from original antibody contained the specificity (Fig. 3), and the in vitro results demonstrated this model kept the same extent specificity as Fab and ScFv did (Fig 2a, 3a). The antigen-recognizing moiety of the conjugated reagent could discern the specific antigens on the breast cancer cell membrane, and guide the colicinderived moiety to form a transmembrane ion-channel and ultimately killed the target cells [15]. Owing to the absence of the specific antigen in the Raji cells, the mimetic moiety should be unable to interact with these cells, so they survived the lethal effects of PMN molecules (Fig. 2a). Not only in vitro condition, but also in vivo condition PMN could present its competency of recognizing specific antigen on target cells and killing them, which was also confirmed by our experiments finding no obvious effects on growth of MCF-7 tumor treated by wt Ia protein (Fig. 4).

Compared to its parental antibody, this small antibody reconstructed following the novel way kept only part 

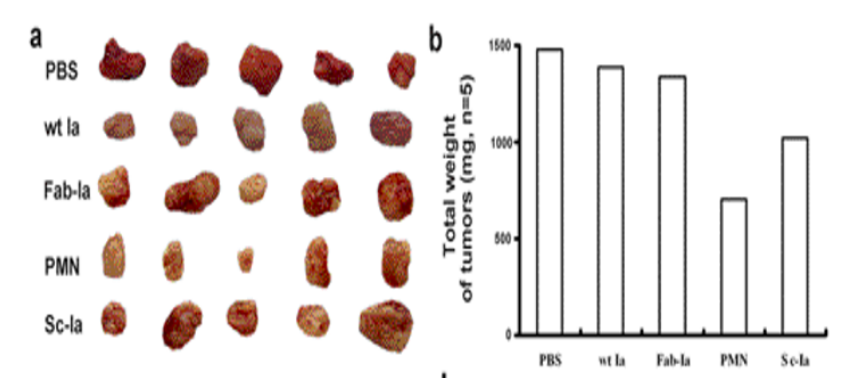

C

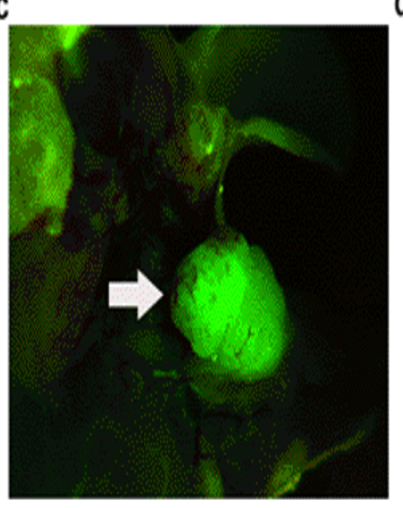

d

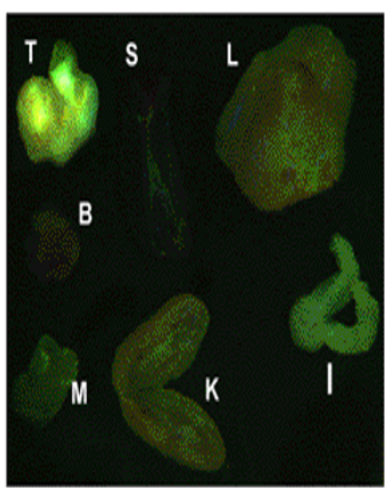

\section{Figure 4}

In vivo killing competency and the biodistribution of PMN. In vivo killing competency was compared with PBS, wt la, Fab-la and Sc-la in BALB/c athymic immunocomposed mice bearing MCF-7 tumors. (a) The tumors of mice were collected after 2-week administration. (b) The weights of each individual tumor were added together and the total weights were compared between groups. Compared with PBS, wt la, Fab-la and Sc-la, PMN could significantly suppress the growth of MCF-7 tumors ( $P<0.05)$. PMN, protomimecin; wt la, wild-type colicin la; Fab-la, Fab segment from original antibody-colicin la fusion peptide; Sc-la, ScFv segment from original antibody-colicin la fusion peptide. (c) Fluorescence images of tumor (white arrow) in BALB/c mice traced by FITC-labeled PMN. The green fluorescence represented the location of FITC-labeled PMN protein. (d) Fluorescence images of incised tumor and vital organs from BALB/c mice traced by ip injecting FITC-labeled PMN. The green fluorescence showed the biodistribution of FITC-labeled PMN. T, tumor; S, spleen; L, liver; B, brain; M, muscle; K, kidney; I, intestine.

affinity to antigen (Fig. 3b). And in vivo results certificated PMN molecules could penetrate into the core area of solid tumors. However, the increased affinity could not improve the penetration into solid tumors [21]. Previous studies had already confirmed that the highest affinity scFv mainly arrested in the perivascular region of solid tumors, whereas the lowest affinity scFv harbored the most uniform biodistribution throughout the tumors [6]. This novel small antibody contained only $10 \sim 15 \%$ original affinity, which assigned the mimetic increased pene- tration and kept the specificity (Fig. 4, 5). Considering the synthetic relationship between specificity and affinity in the procedure of interacting of antibody to antigen $[1,2,7]$, under the condition of keeping original specificity, maybe the reduced affinity of those rebuilt small antibodies could give a more better solution to the "bindingbarrier" of solid tumors than only keeping the single specificity or affinity.

In vitro results indicated that the Fab and Sc-Fv signals could guide the "killing moiety" to kill breast cancer cells, but those phenomena could not be re-presented in vivo. It was suggested that the solid tumors, especially malignant tumors have interstitial fluid pressure in their tissues because of the eugonic state, which prevents the diffusion of any forms of treatment medicines into the core area of solid tumors, especially those large peptide molecules such as native antibody Fab and ScFv segments [22,23]. By pathological staining, we found numerous fibrous foci in the core area of the tumors from treated mice, which were not inspected on tumors from the control animals including the Fab-Ia and Sc-Ia groups (Fig. 5), indicating that PMN molecules could efficiently penetrate into the core area of solid tumor and kill target cells. Previous studies on exnograft MCF-7 tumors show no evidence of metastasis and no obvious fibrosis, which is consistent with our results [24] (Fig. 5a). We observed that the parenchyma of treated tumors presented numerous areas of embedded fibrous tissue, indicating that the parenchyma was substituted by fibers and other connective tissue components after necrosis (Fig. 5b). Compared with the control group tumors, which showed much parenchyma with little abnormal connective tissue, the pathological difference between the tumors from PMN-treated and control groups may be more important than just the weight difference between the groups, although the total tumor weight difference from groups was significant $(p<0.05)$ after 2 week treatment.

Furthermore, we found expression intensity of c-erbB-2 antigen was higher on Zr-75-30 than on MCF-7 cells, but those reagents including PMN, Fab-Ia and Sc-Ia fusion peptides produced no obvious effects on Zr-75-30 cells in vitro (Fig. 2a), which was also found in previous studies, showing that the same antibody conjugated to toxins or other reagents could not always present the same killing competency in all tested cell lines $[14,15,25,26]$. However, for PMN, Fab-Ia and Sc-Ia, we believed that a "binding barrier" [6], originating from intensive interactions between the antigen and antibody, prevented the $\alpha$-helix hairpin of the channel-forming domain of colicin Ia from approaching the plasma membrane $[15,16]$, which blocked the killing effect. Furthermore, the mimetic generally kept only $10 \sim 15 \%$ affinity of parental antibody to antigen (Fig. 3b). More importantly, the c-erbB-2 mem- 

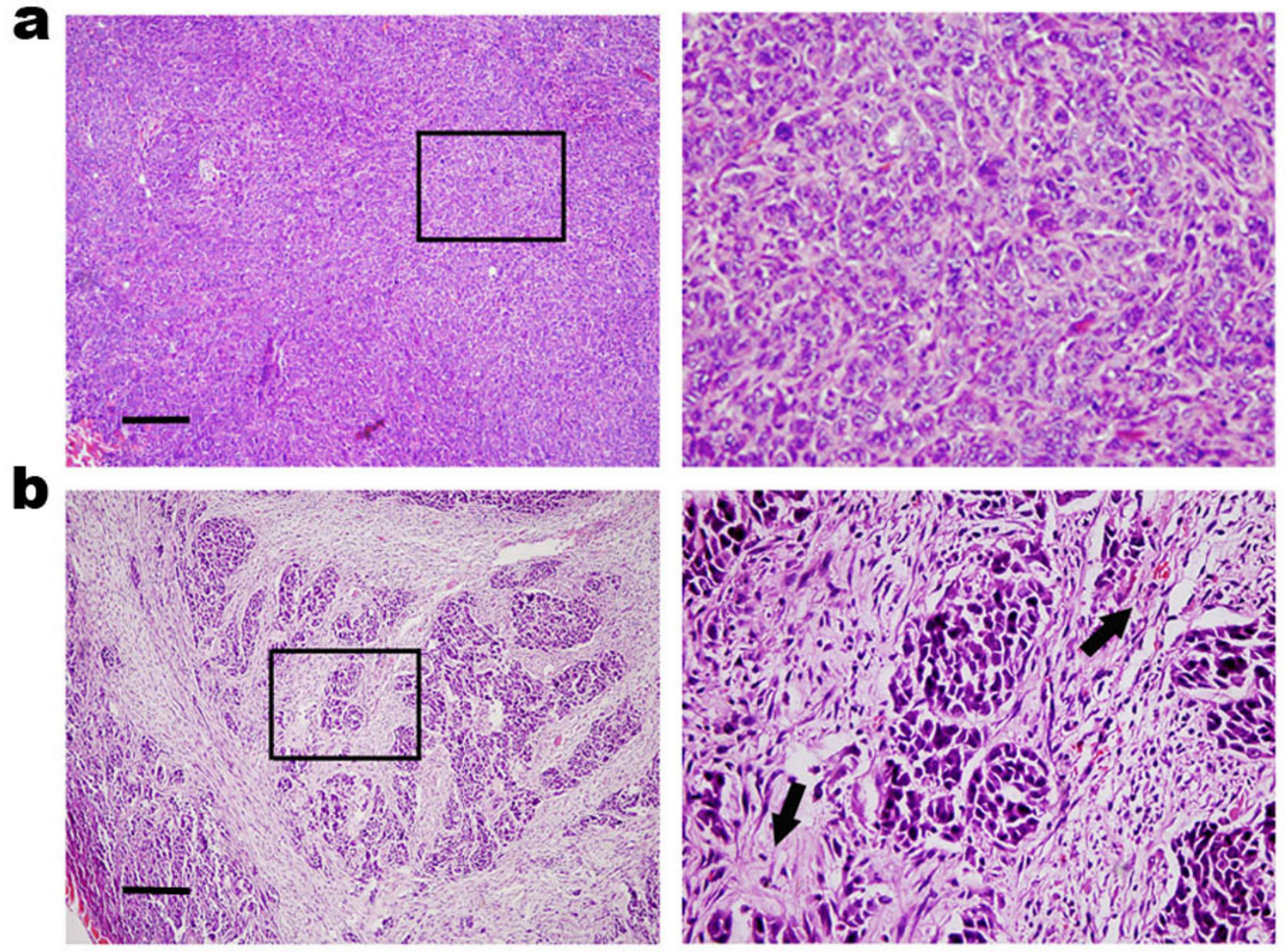

Figure 5

Histopathological staining revealed numerous fibrous foci (black arrow) in the tumors from the treated group with PMN (b), which were not seen in the other control groups (a). PMN, protomimecin. Scale bar, $50 \mu \mathrm{m}$.

brane glycoprotein is a complicated antigen, and contains different epitopes on its surface. Although almost all of those breast cancer cells express the same antigen c-erbB2 , the precise epitope and the specific targeting site may be different to each other. However, the precise reason for the reduced efficacy to other breast cancer cell lines remains to be resolved.

The PMN peptide molecule mainly consists of conlicin Ia (Fig. 1). The E1 colicin family protein are produced by $E$. coli and permanently existed in live beings. And because of the parasitism of $E$. coli in intestine, which means this peptide is an immunological tolerant protein for those parasitifers. Our bio-safe assessment assays demonstrated the safety of this novel fusion peptide, showing all the experimental animals gained body weight during experiments, and no microscopic evidences of metastasis, necrosis, inflammation and lymphocyte infiltration were detected in liver, kidney, intestine, lung and spleen from groups treated by PMN. Those results suggested the in vivo bio-safety of the novel peptide could be assured. But the potential toxicity of the toxin-mimetic conjugated peptide remains to be investigated before using in human.

\section{Conclusion}

The present research confirmed that the novel mimetic maintained the specificity of the original antibody, and could guide a functional moiety to the target cell membrane to cause specific cell death without any apparent adverse effects. Further experiments are needed to study the efficacy of this novel mimetic therapy; nevertheless the study provides proof of concept that this novel model of rebuilding antibody molecules offers additional treatment modalities for targeted therapy of solid tumors.

\section{Competing interests}

The authors declare that they have no competing interests. 


\section{Authors' contributions}

ZPZ and JZ prepared mimetic and fusion molecules, measured in vitro and in vivo killing activity and did pathological assays; SYZ did DNA scanning and SDS-PAGE.

\section{Acknowledgements}

This work was supported partly by Feng-Li Cai, Yu-Chuan Huang, Sheng-Fu $\mathrm{Li}$ and Dan Long from The Key Laboratory of Transplant Engineering and Immunology, Ministry of Health, West China Hospital, Sichuan University, China.

\section{References}

I. Viterra ES, Fulton RJ, May RD, Till M, Uhr JW: Redesigning Nature's Poisons to Create Anti-Tumor Rereagents. Science 1987, 238: 1098-II04.

2. Weiner LM: Building better magic bullets - improving unconjugated monoclonal antibody therapy for cancer. Nature Reviews Cancer 2007, 7:70I-706.

3. Tonegara S: Somatic generation of antibody diversity. Nature 1983, 302:575-58|.

4. Kohler G, Milstein C: Continuous cultures of fused cells secreting antibody of predefined specificity. Nature 1975, 256:495-497.

5. Padlan EA: Anatomy of the antibody molecule. Molecular Immunology 1994, 31:169-217.

6. Adams GP, Schier R, McCall AM, Simmons HH, Horak EM, Alpaugh RK, Marks JD, Weiner LM: High affinity restricts the localization and tumor penetration of single-chain $\mathrm{Fv}$ antibody molecules. Cancer Res 200I, 6 I:4750-4755.

7. Hudson PJ, Kortt AA: High avidity scFv multimers; diabodies and triabodies. J Immunol Methods 1999, 23 I:177-189.

8. Holliger P, Hudson P: Engineered antibody fragments and the rise of single domains. Nature Biotechnology 2005, 23: I I 26-I I 36.

9. Casset F, Roux F, Mouchet P, Bes C, Chardes T, Granier C, Mani JC, Pugnière M, Laune D, Pau B, Kaczorek M, Lahana R, Rees A: A peptide mimetic of an anti-CD4 monoclonal antibody by rational design. Biochem Biophys Res Com 2003, 307:198-205.

10. Edmundson $A B$, Ely KR, Abola EE: Conformational flexibility in immunoglobulins. In Contemporary Topics in Molecular Immunology. New York, Plenum Publ Corp; 1978: 137-I56.

11. Souriau C, Chiche L, Irving R, Hudson P: New binding specificities derived from Min-23, a small cysteinestabilized peptide scaffold. Biochemistry 2005, 44:7|43-7I55.

12. Aburatani $\mathrm{T}$, Ueda H, Nagamune T: Importance of a CDR $\mathbf{H}_{3}$ basal residue in $\mathrm{VH} / \mathrm{VL}$ interaction of human antibodies. $J$ Biochem 2002, I32:775-785.

13. Ring DB, Kassel JA, Hsieh-Ma ST, Bjorn MJ, Tringale F, Eaton AM, Reid $S A$, Frankel AE, Nadji M: Distribution and physical properties of BCA200, a Mr 200,000 glycoprotein selectively associated with human breast cancer. Cancer Research 1989, 49:3070-3080.

14. Ring DB, Clark R, Saxena A: Identity of BCA200 and c-erbB-2 indicated by reactivity of monoclonal antibody wiwh recombinant c-erbB-2. Molecular Immunology 1991, 28:915-917.

15. Kienker PK, Qiu XQ, Slatin SL, Finkelstein , Jakes KS: Transmembrane insertion of the colicin la hydrophobic hairpin. J Memb Biol 1997, 1 57:27-37.

16. Qiu XQ, Jakes KS, Kienker PK, Finkelstein A, Slatin SL: Major transmembrane movement associated with colicin la channel gating. J Gen Physiol 1996, 107:3 I3-28.

17. Alfthan K, Takkinen K, Sizmann D, SSderlund H, Teeri TT: Properties of a single-chain antibody containing different linker peptides. Protein Engineering 1995, 8:725-73I.

18. Borg NA, Ely LK, Beddoe T, Macdonald WA, Reid HH, Clements CS, Purcell AW, Kjer-Nielsen L, Miles J], Burrows SR, McCluskey J, Rossjohn J: The CDR3 regions of an immunodominant $T$ cell receptor dictate the 'energetic landscape' of peptide-MHC recognition. Nat Immunol 2005, 6: I7I-I80.

19. Laune D, Molina F, Ferrieres G, Mani JC, Cohen P, Simon D, Bernardi T, Piechaczyk M, Pau B, Granier C: Systematic exploration of the antigen binding activity of synthetic peptides isolated from the variable regions of immunoglobulins. J Biol Chem 1997, 272:30937-30944
20. Ewert S, Huber T, Honegger A, Pluckthun A: Biophysical properties of human antibody variable domains. J Mol Biol 2003, 325:53I-553.

21. Carter PJ: Potent antibody therapeutics by design. Nat Rev Immunol 2006, 6:343-357.

22. Jain RK: The next frontier of molecular medicine: delivery of therapeutics. Nature Medicine 1998, 4:655-57.

23. Heldin $\mathrm{CH}$, Rubin K, Pietras K, Ostman A: High interstitial fluid pressure - an obstacle in cancer therapy. Nature Rev Cancer 2004, 4:806-13

24. Akiri G, Sabo E, Dafni H, Vadasz Z, Kartvelishvily Y, Gan N, Kessler O, Cohen T, Resnick M, Neeman M, Neufeld G: Lysyl oxidaserelated protein-I promotes tumor fibrosis and tumor progression in Vivo. Cancer Research 2003, 63:1657-1666.

25. Bjorn MJ, Groetsema G, Scalapino L: Antibody-Pseudomonas Exotoxin A Conjugates Cytotoxic to Human Breast Cancer Cells in Vitro. Cancer Research 1986, 46:3262-3267.

26. Lanteri M, Ollier L, Giordanengo V, Lefebvre JC: Designing a HER2/neu promoter to drive $\alpha \mathrm{l}, 3$ galactosyltransferase expression for targeted anti- $\alpha \mathbf{G a l}$ antibody-mediated tumor cell killing. Breast Cancer Research 2005, 7:R487-R494.
Publish with BioMed Central and every scientist can read your work free of charge

"BioMed Central will be the most significant development for disseminating the results of biomedical research in our lifetime. "

Sir Paul Nurse, Cancer Research UK

Your research papers will be:

- available free of charge to the entire biomedical community

- peer reviewed and published immediately upon acceptance

- cited in PubMed and archived on PubMed Central

- yours - you keep the copyright
BioMedcentral 